\title{
Distributed Generation: A Critical Review of Technologies, Grid Integration Issues, Growth Drivers and Potential Benefits
}

\author{
Pavan Khetrapal
}

\author{
Institute of Technology, Nirma University, Ahmedabad, India - 382481
}

\begin{abstract}
Owing to liberalization of electricity market, technology evolution, energy security, environmental issues and growing concerns of energy cost, the penetration of distributed energy units in distribution network is increasingly observed worldwide. Penetrating embedded generation, or distributed generation (DG), in power distribution grid requires a number of issues to be considered, such as definition of DG, rating of DG, the best DG technology etc. This paper presents an extensive critical review of various dimensions of distributed generation (DG) including definitions, generation technologies and their status, impact on distribution network performance etc. The study also presents comparative study between the various technologies in terms of most important technological characteristics of each DG technology. The policy makers, utility regulators and DG planning engineers can use this critical review, without going through complicated computations, as guidelines to make policies, standards and decisions in DG penetration and related issues. C2020. CBIORE-IJRED. All rights reserved
\end{abstract}

Keywords: Distributed generation, distribution system, renewable energy sources, DG benefits .

Article History: Received: 21 ${ }^{\text {st }}$ March 2020; Revised: 26 $6^{\text {th }}$ April 2020; Accepted: $30^{\text {th }}$ April 2020; Available online: $2^{\text {nd }}$ May 2020

How to Cite This Article: Khetrapal, P. (2020) Distributed Generation: A Critical Review of Technologies, Grid Integration Issues, Growth Drivers and Potential Benefits. International Journal of Renewable Energy Development, 9(2), 189-205

https://doi.org/10.14710/ijred.9.2.189-205

\section{Introduction}

Since the emergence of Alternating Current (AC) electrical systems and the ability to transport large blocks of power over long distances, the top - down paradigm has governed electricity generation and supply. This concerned large scale generation feeding into high voltage transmission systems which transferred power to medium voltage distribution networks and on to low voltage customer level. Considering the way in which the very earliest electricity utilities were functioning to generate and distribute electricity, it is apparent that the idea behind the distributed generation (DG) is not entirely new at all. Network operators had their own assigned service areas, generating and delivering electricity to the consumers in their assigned geographical regions (Mehigan et al., 2018). National electric grids then were recognized and came along to develop large interconnected power networks that provided more reliable, economic and efficient power systems (Perez-Arriaga, 2016; Manfren et al., 2011).

In recent years, the electricity supply framework and its associated transmission and distribution systems, has observed significant changes throughout the world. The driving forces behind these changes mainly include regulatory issues, reliability, security, technological advances (evolution of Smart Grids) and emissions reduction concerns. The growth of competition in the electricity market, the development of renewable electricity generation technologies, concerns over ageing infrastructure, and capacity constraints have stimulated increasing participation of DG technologies in power systems to address such key issues (Carley, S, 2009). Additionally, in the liberalized electricity market of today, the market players are not easily convinced to take investment decisions in multibillion power generation and transmission projects because of very long payback period. These key concerns, and the liberalization of the electricity sector and decentralization of power systems, along with exponentially growing consumers' demand globally has made DG technologies an attractive and viable solution to provide power generation of the future (Allan et al., 2015). Further, the integration of diverse DG sources to the utility network will offer a number of benefits such as improved reliability, power quality, efficiency, alleviation of system constraints along with the environmental benefits. With these benefits and due to the growing momentum towards sustainable energy developments, it is expected that large number of DG systems will be interconnected to the power system in the coming years (Chmutina and Goodier, 2014; Vahl et al., 2013).

Despite these potential theoretical benefits of distributed energy generation, there are still complexities and constraints (technical, economic and regulatory) involved in its further penetration into the energy mix, and also restricting progress towards a new model of electric networks (Adil and Ko, 2016). However, these issues and complexities must be addressed and resolved, to pave the way for a sustainable energy future based on a large share of DG. Further, the issues pertaining to DG 
integration with grid; and several other factors such as which best DG technology to be used; the best location etc. are also required to be considered while carrying out studies related to the planning and operational aspects of DG (Colmenar et al., 2016; CIGRE, 1998). In this context, the objective of the present paper is to provide a comprehensive review of distributed generation definitions and technologies, drivers towards DG growth, and the benefits offered by DG integration to the distribution network.

\section{DG Definitions}

The prevailing literature on DG shows that the definitions used for DG are not consistent and yet there is no generally adopted definition of DG by the utilities (Pepermans et al., 2005; IEA, 1997). The United States Department of Energy (US - DOE) defines DG as follows: "Distributed Generation is the integrated or stand-alone use offsmall, modular energy (electric and/or thermal) generation resources, located near the consumption of energy. Distributed systems include wind turbines, microturbines, fuel cells, engines/generators sets, thermal solar and photovoltaic systems, combustion turbines, biomass - based generators, and storage and control techniques. Distributed technologies can either be independent of the grid or grid connected (Ackermann et al., 2001; Hadisaid, et al., 1999). The Institute of Electrical and Electronics Engineering (IEEE) adopted the definition of DG as "the electricity generation by facilities sufficiently smaller than centralized generating power plants, usually $10 \mathrm{MW}$ or smaller, so as to allow interconnection at nearly any point in the electric power system". Nevertheless, the following definition for DG is generally agreed in the literature: "A small scale power generating source connected directly to the grid at distribution level voltage or on the consumer site of the meter". This definition generally incorporates DG technologies such as: concentrating solar power and photovoltaic, fuel cells, microturbines, and reciprocating engines. Moreover, in the literature, a large number of terminologies and definitions such as decentralized generation, distributed energy resources or DER, dispersed generation and embedded generation have also been used in relation to distributed generation (Willis and Scott, 2000).

In addition, in regards to the specification of DG power units, some countries define DG according to its voltage level at which it is interconnected, while other countries follow the principle that Distributed Generation is connected to circuits that feed directly to consumer loads". Although, there is no commonly accepted standard or rule, the following ratings are currently used in various countries and situations (Pepermans et al., 2005; Ackermann et al., 2001; Hadisaid, et al., 1999):

- The International Council on Large Electricity Systems (CIGRE) defines DG as generating units with rating less than $100 \mathrm{MW}$, that are neither centrally planned not centrally dispatched and usually connected to the distribution network (CIGRE, 1998).

- Australian Energy Market Operator (AEMO) considers generating plants having capacity maximum upto $30 \mathrm{MW}$ as DG.
- In New Zealand, power generating plants of capacity less than $5 \mathrm{MW}$ are usually defined as DG.

- The State Owned Bulgarian Energy Holding Company defines DG as generating sources less than $10 \mathrm{MW}$, not centrally planned and connected to the distribution network.

- In Estonian power markets, sources less than 50 MW for local consumption and/or for selling to the utility are considered as DG.

- The Electric Power Research Institute (EPRI), defines DG as generating units ranging from a few $\mathrm{kW}$ to $50 \mathrm{MW}$, typically located at the customer site or distribution and sub - transmission substations.

- The Gas Research Institute, treats generating units typically ranging between $25 \mathrm{~kW}$ and $25 \mathrm{MW}$ as DG.

- Dondie et al. (2002) define distributed generation as a small source of electric power generation for storage (typically ranging from less than a $\mathrm{kW}$ to tens of MW) that is not a part of a large central power system and is located close to the load.

- Chambers (2001) also defines distributed generation as relatively small generation units of $30 \mathrm{MW}$ or less. These units are sited at or near customer sites to meet specific customer needs, to support economic operation of the distribution grid, or both.

- The English and Welsh electricity markets, considers power generating units with capacity less than $100 \mathrm{MW}$ and is not centrally dispatched as DG.

- In Sweden, all those generating units having capacity maximum upto $1500 \mathrm{~kW}$ are defined as DG.

It is clear from the above discussion that owing to large diversity in government regulating policies, the DG definitions and ratings significantly vary from one country to another, and it is difficult to extract a unique criterion in specifying the capacity ratings for DG units. The various criteria that forms the basis for classification of DG are as follows:

a. On the basis of point of DG connection: The definition of the location of the distributed generation plants varies among different authors. Most authors define the location of DG at the distribution side of the network, some authors also include the customers side, and some even include the transmission side of the network.

b. On the basis of capacity: The maximum rating of the DG which can be connected to distributed generation depends on the capacity of the distribution system that is interrelated with the voltage level of the distribution system. Hence, the capacity of DGs can vary widely.

c. On the basis of Purpose of Interconnection: Generation units should by definition at least supply active power in order to be considered as distributed generation. The supply of reactive power and/or other ancillary services is possible and may represent an added value, but is not necessary. 
d. On the basis of DG Technology: Often the term distributed generation is used in combination with a certain generation technology category, e.g. non renewable and renewable energy technology.

e. On the basis of Ownership: It is frequently argued that DG has to be owned by independent power producers or by the customers themselves, to qualify as DG. Ackermann et al. (2001) do not consider ownership as a relevant element for the definition of distributed generation. Thus, customers, IPPs and traditional generators can own distributed generation units

Figure 1 depicts the various criteria which can form the basis for defining DG.

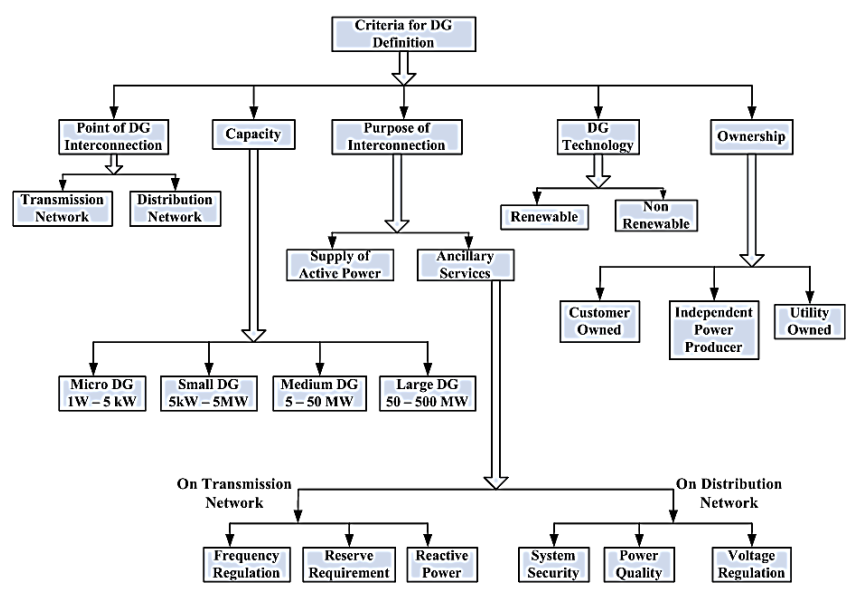

Fig. 1 Criteria for classification of DG

\section{DG Technologies}

The growing concern of governments, on a global level, to move towards low-carbon economy and sustainable growth targets has brought about the rapid proliferation of distributed power generation. DG technologies are usually classified into two broad categories: non renewable (fuel - based) and renewable (non - fuel - based) energy sources. Non - renewable energy technologies use fossil - based fuels such as gasoline, idiesel, oil, propane, methane, natural gas, or coal source. Fossil fuel based DGs are not considered sustainable electricity generation sources because their energy source will not renew or replenish. Examples of non-renewable technologies include reciprocating engines, internal combustion gas turbines (ICGT), microturbines, and fuel cells. Distributed renewable energy technologies are in general sustainable (i.e. their primary energy source will not run out) and cause minimum or no environmental concerns. The DG technologies that fall under this category comprise wind turbines, solar thermal, solar photovoltaic, biomass and biogas, ocean and geothermal (tidal and waves) energy systems, small/mini/micro hydro power, and hydrogen fuel cells. The contribution potential of renewable energies in all countries is growing rapidly as the technology matures. The renewable energy sources contribute to the diversity of energy supply portfolio, mitigate the greenhouse gas emissions, and reduce the risks of continued use.of fossil fuels and nuclear power (Borbely and Kreider, 2001; Khattam and Salama, 2004).
A classification of various DG technologies is presented in Figure 2 and are discussed in following subsections.

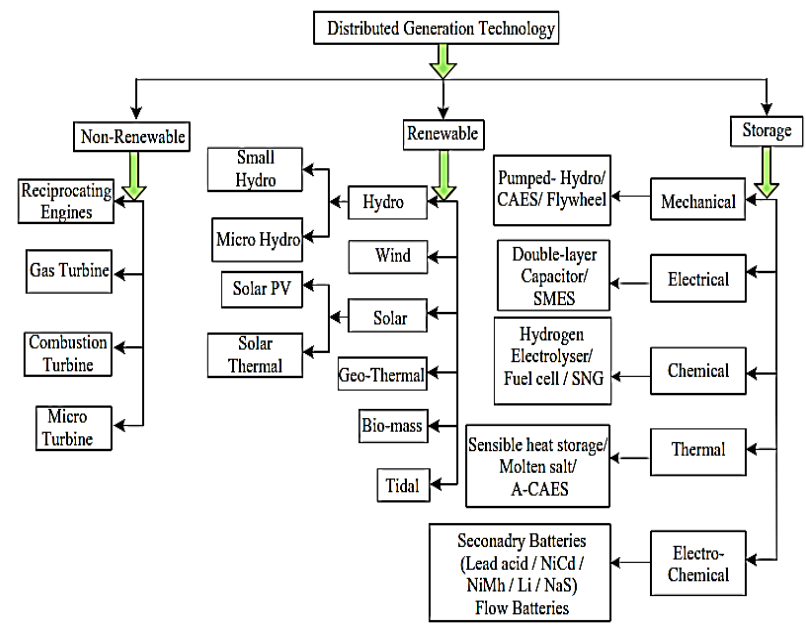

Fig. 2 Classification of DG Technologies

\subsection{Conventional DG Technologies}

\subsubsection{Reciprocating Internal Combustion Engines:} Reciprocating engines also known as piston engines were the first fossil-fuel-driven DG technologies developed more than 100 years ago and use diesel, natural gas, or waste gas as their fuel source. The reciprocating engines are highly flexible and suitable for several applications, among which are electric power generation, combined heat and power generation (CHP) and mechanical prime movers for many equipment and propulsion. The reciprocating technologies can operate as a stand-alone to meet the power demands of consumer in remote locations or grid-connected power system, where it can feed the surplus to the grid having met the power requirements of the local consumers. The power generation scales of the reciprocating engines are differed from the $1 \mathrm{kVA}$ (small scale) to several tens of MVA (large scale) (Chambers, 2001; Banerjee, 2006).

The schematic operation diagram of a reciprocating engine, which operates in four cycles for power generation is shown in Figure 3 and the schematic diagram of a combined heat and power (CHP) system is shown in Figure 4.

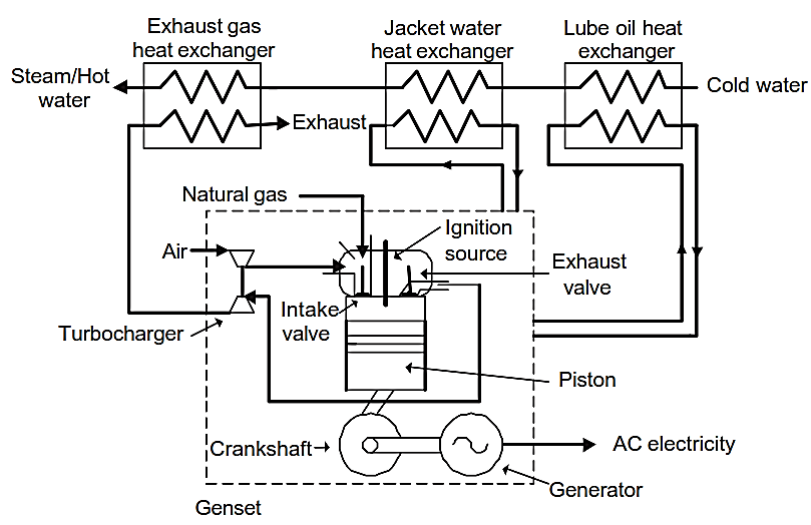

Source: [Chambers, 2001]

Fig. 3 Schematic operating principle of reciprocating engine 


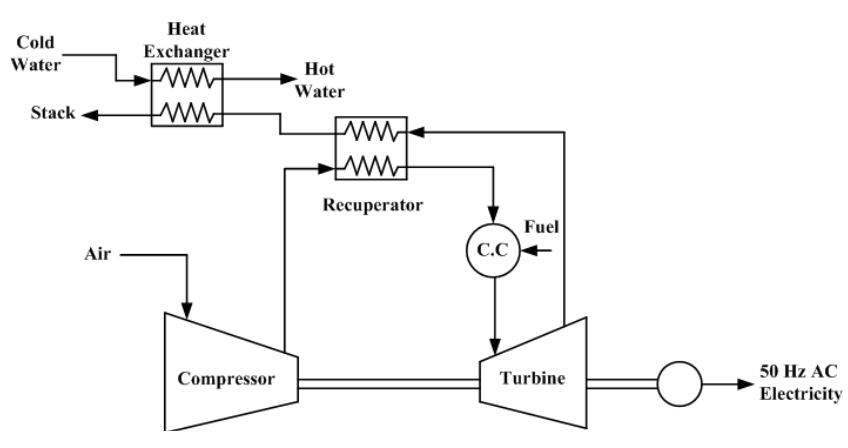

Source: [Chambers, 2001]

Fig. 4 Schematic diagram of a combined heat and power (CHP) system

The reciprocating engines provide the lowest cost of all combined heat and power (CHP) systems, high efficiencies (37-44\% diesel-fired, 29-43\% gas-fired), short start-up times to full loads $(12-16 \mathrm{~s})$, and high reliability. The main drawbacks of reciprocating engines are noise, costly maintenance and high emissions, particularly of nitrogen oxides. These emissions can be reduced, with a loss of efficiency, by changing combustion characteristics. Catalytic converters are a proven emissions-control technology. The power generation from the reciprocating power units represents about $11-16 \%$ of the world power demand and have the capacity to supply $23.8 \%$ of the global electricity demand (Borbely and Kreider, 2001).

3.1.2 Microturbines: Microturbines were initially developed for the transportation sector and more recently have found a place in the power generation sector. Microturbine units can use a wide range of fuels such as natural gas, hydrogen, propane and diesel to produce electricity. The schematic of a typical microturbine is shown in Figure 5.

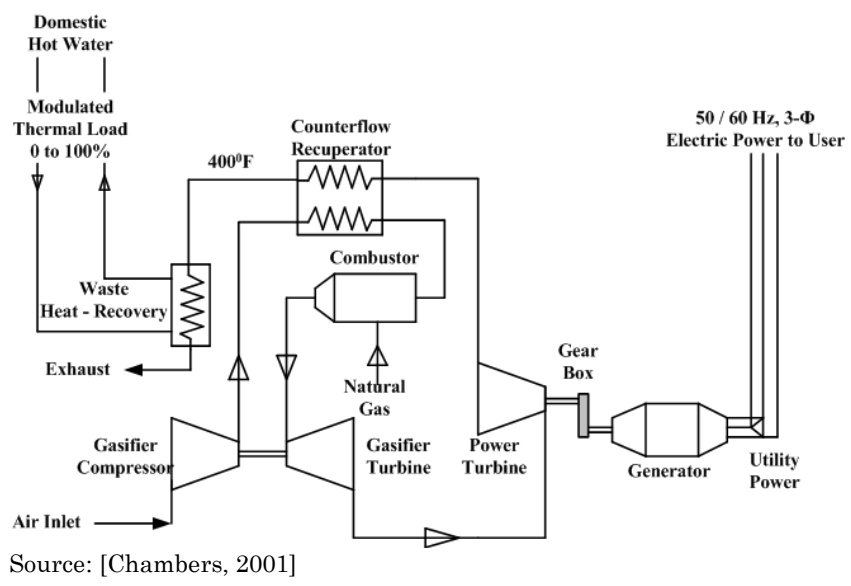

Fig. 5 Schematic diagram of a typical microturbine

Microturbines can be used for base load power, stand-by power, peak shaving and cogeneration applications and well-suited for small commercial buildings. The capacity of microturbines range from $25 \mathrm{~kW}$ to $500 \mathrm{~kW}$ and have an electrical efficiency of about $15 \%$ for unrecuperated type and between $20 \%$ and $30 \%$ for recuperated types, which recover exhaust heat to boost the temperature of combustion. The start-up time for commercial microturbines has been reported to be up to 120 seconds.
Microturbine DG units have a good $\mathrm{NO}_{x}$ emissions performance $(0.1 \mathrm{~kg} / \mathrm{MWh})$; however, their $\mathrm{CO}_{2}$ emissions are sometimes more than ICE DG units $(720 \mathrm{~kg} / \mathrm{MWh})$. The capital costs of installing microturbines are estimated to be between 700 and $1100 \mathrm{US} \$ / \mathrm{kW}$ and the maintenance costs is between 0.005 and $0.016 \mathrm{US} \$ / \mathrm{kW}$. The main advantages of microturbines are low noise, small size, small number of moving parts, long maintenance intervals and ability to use waste fuels. In comparison with ICE engines, microturbines still have high capital costs (Jenkins et al., 2000).

3.1.3 Combustion Gas Turbines: Historically, combustion gas turbines (CGTs) were developed as aero derivatives using jet propulsion engines as a design base. However, in oil and gas industries, they have been designed specifically for stationary power generation or for compression applications. Gas turbine power generators are used in two basic configurations.

a. Simple Systems: This system consists of the gas turbine driving an electrical power generator. Figure 6 depicts such a configuration.

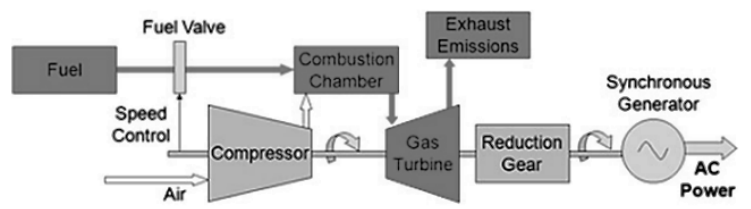

Source: [NREL, 2003]

Fig. 6 Schematic diagram of Simple Systems

b. Combined Cycle Systems: These systems are designed for maximum efficiency in which the hot exhaust gases from the gas turbine are used to raise steam to power a steam turbine with both turbines being connected to electricity generators (see Figure 7).

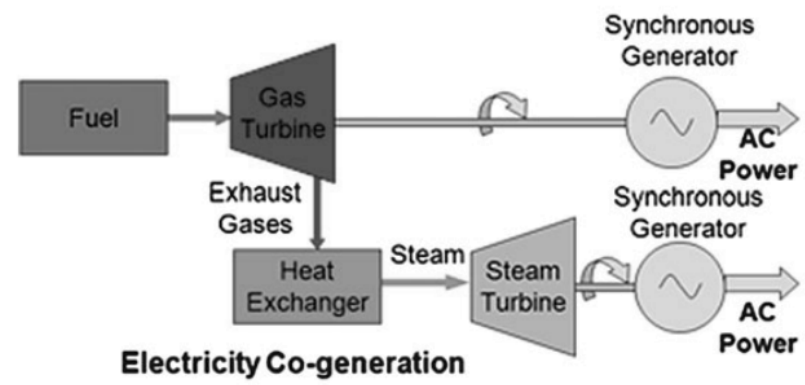

Source: [NREL, 2003]

Fig. 7 Schematic diagram of Combined Cycle Systems

They are usually used in the $500 \mathrm{~kW}$ to $30 \mathrm{MW}$ range in CHP applications and are available up to 265MW. For unit capacities less than $100 \mathrm{~kW}$, the efficiency varies between 15 to $17 \%$, while for units larger than $30 \mathrm{MW}$, it is as high as $45 \%$ for simple cycle turbines. Part load efficiency of CGTs is lower than full load efficiency and their output and consumption decreases in higher altitude regions. Combined cycle turbines can reach efficiencies up to $55 \%$, but are usually used as central power plants and not as 
DG units. The typical efficiency is around $35 \%$ in the 5 MW range.

Comparatively low capital cost, availability of natural gas with low and fixed price in most countries, good efficiency and low installation time are the advantages of gas turbines. Furthermore, typical start up time to full output power is between 210 minutes, which makes gas turbines a good choice for reserve support. Although the $\mathrm{CO}_{2}$ emissions of gas turbines are nearly like engines (582-681 kg/MWh), they have significantly lower $\mathrm{NO}_{x}$ emissions $(0.3-0.5$ $\mathrm{kg} / \mathrm{MWh}$ ). The promising developments in small size gas turbines markets also represent the growing trends toward DG in the power generation business (NREL, 2003).

Table 1

Comparison of Different Fuel cells

\begin{tabular}{|c|c|c|c|c|c|}
\hline Fuel Cell Type & PEMFC & PAFC & MCFC & SOFC & AFC \\
\hline Anode & Platinum & Platinum & Steel / Nickel & Ceramic & Platinum or Carbon \\
\hline Electrolyte & $\begin{array}{l}\text { Perfluorosulfonic } \\
\text { acid }\end{array}$ & $\begin{array}{l}\text { Phosphoric acid } \\
\text { soaked in a matrix }\end{array}$ & $\begin{array}{l}\text { Molten lithium, sodium, } \\
\text { and / or potassium } \\
\text { carbonates, soaked in a } \\
\text { porous matrix }\end{array}$ & $\begin{array}{l}\text { Yttria } \\
\text { Zirconia }\end{array}$ & $\begin{array}{l}\text { Aqueous solution of } \\
\text { potassium hydroxide } \\
\text { soaked in a matrix }\end{array}$ \\
\hline Operating & $50-100^{\circ} \mathrm{C}$ & $150-200^{\circ} \mathrm{C}$ & $600-700^{\circ} \mathrm{C}$ & $500-1000^{\circ} \mathrm{C}$ & $90-100^{\circ} \mathrm{C}$ \\
\hline Temperature & $\begin{array}{l}122-212^{\circ} \mathrm{F} \\
\text { Typically } 80^{\circ} \mathrm{C}\end{array}$ & $302-392^{\circ} \mathrm{F}$ & $1112-1292^{\circ} \mathrm{F}$ & & $194-212^{\circ} \mathrm{F}$ \\
\hline Efficiency & $\begin{array}{l}60 \% \text { Transportation } \\
35 \% \text { Stationary }\end{array}$ & $\begin{array}{l}40-50 \% \\
(80 \% \mathrm{CHP})\end{array}$ & $45-50 \%$ & $35-43 \%$ & $60 \%$ \\
\hline $\begin{array}{lr}\text { Typical } & \text { Stack } \\
\text { Size / } & \text { Power } \\
\text { Output } & \end{array}$ & $<1 \mathrm{~kW}-100 \mathrm{~kW}$ & $\begin{array}{l}400 \mathrm{~kW} \\
100 \mathrm{~kW} \text { module }\end{array}$ & $\begin{array}{l}300 \mathrm{~kW}-3 \mathrm{MW} \\
300 \mathrm{~kW} \text { Module }\end{array}$ & $1 \mathrm{~kW}-2 \mathrm{MW}$ & $10-100 \mathrm{~kW}$ \\
\hline Advantages & $\begin{array}{l}\text { - Solid electrolyte } \\
\text { reduces corrosion } \\
\text { and electrolyte } \\
\text { management } \\
\text { problems } \\
\text { - Low Temperature } \\
\text { - Quick Start - up }\end{array}$ & $\begin{array}{l}\text { - High temperature } \\
\text { enables CHP } \\
\text { - Increased tolerance } \\
\text { to fuel impurities }\end{array}$ & $\begin{array}{l}\text { - High efficiency } \\
\text { - Fuel flexibility } \\
\text { - Can use a variety of } \\
\text { catalysts } \\
\text { - Suitable for CHP }\end{array}$ & $\begin{array}{l}\text { - High efficiency } \\
\text { - Fuel flexibility } \\
\text { - Suitable for CHP } \\
\text { - Hybrid / gas turbine } \\
\text { cycle }\end{array}$ & $\begin{array}{l}\text { - Cathode reaction } \\
\text { faster in alkaline } \\
\text { electrolyte, leads to } \\
\text { high performance } \\
\text { - Low cost components }\end{array}$ \\
\hline Disadvantages & $\begin{array}{l}\text { - Expensive } \\
\text { Catalysts } \\
\text { - Sensitive to fuel } \\
\text { impurities. } \\
\text { - Low Temperature } \\
\text { waste heat }\end{array}$ & $\begin{array}{l}\text { - Expensive Catalysts } \\
\text { - Long start - up time } \\
\text { - Sulphur Sensitivity }\end{array}$ & $\begin{array}{l}\text { - High temperature } \\
\text { corrosion } \\
\text { - Long start - up time } \\
\text { - Low power density }\end{array}$ & $\begin{array}{l}\text { - High temperature } \\
\text { corrosion } \\
\text { - Long start-up time } \\
\text { - Limited number of } \\
\text { shut downs }\end{array}$ & $\begin{array}{l}\text { - Sensitive to } \mathrm{CO}_{2} \text { in fuel } \\
\text { and air } \\
\text { - Electrolyte } \\
\text { management } \\
\text { - Electrolyte } \\
\text { conductivity }\end{array}$ \\
\hline Applications & $\begin{array}{l}\text { - Backup Power } \\
\text { - Portable Power } \\
\text { - Distributed } \\
\text { - Generation } \\
\text { - Transportation }\end{array}$ & $\begin{array}{l}\text { - Distributed } \\
\text { Generation }\end{array}$ & $\begin{array}{l}\text { - Electric Utility } \\
\text { - Distributed Generation }\end{array}$ & $\begin{array}{l}\text { - Electric Utility } \\
\text { - Distributed } \\
\text { Generation } \\
\text { - Auxiliary Power }\end{array}$ & $\begin{array}{l}\text { - Backup Power } \\
\text { - Transportation } \\
\text { - Military Space }\end{array}$ \\
\hline
\end{tabular}

Source: [San, Martin et al., 2010]

3.1.4 Fuel Cells: Fuel cells can convert chemical energy to electricity without combustion. Fuel cell technologies were initially developed for space applications, and then the transportation sector found it to be a promising technology. Since this technology has good efficiency, compact in size, very low noise, negligible $\mathrm{NO}_{x}, \mathrm{SO}, \mathrm{CO}$ and reliable operation, it has found its market in the power industry as well. The working principle of a fuel cell is shown in Figure 8.

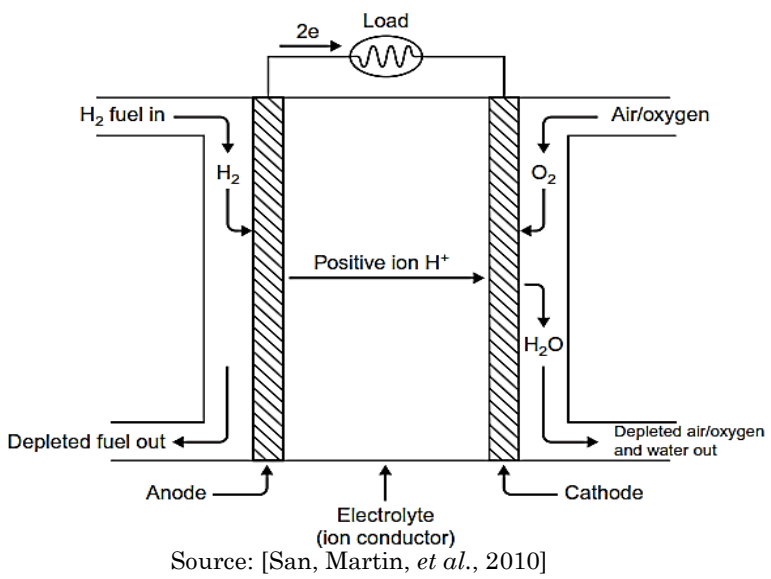

Fig. 8 Fuel Cell operating principle
Five principle types of fuel cells are currently the focus of intensive research and development. These five fuel cell types significantly differ from each other in various aspects; however, the key distinguishing feature is the electrolyte material and operating temperature, which is generally used to identify each of the five fuel cell types:

a. Proton Exchange Membrane fuel cell (PEMFC);

b. Phosphoric Acid fuel cell (PAFC);

c. Molten Carbonate fuel cell (MCFC);

d. Solid Oxide fuel cell (SOFC);

e. Alkaline fuel cell (AFC)

The last category was specially designed for domains related to space. Table 1 gives a summary of the characteristics of different fuel cells (IEA, 2002; San Martín, 2010).

3.1.5 Energy Storage Systems: Energy storage technologies convert and store electricity, increasing the value of power by allowing better utilization of off-peak generation and the mitigation of power fluctuations from intermittent renewable energy generation. Energy storage technologies allow electricity to be stored either directly or by employing a conversion process. Energy storage (ES) system has become an inevitable element in smart distribution network due to massive deployment of 
renewable energy resources (RERs). ES is capable of solving a number of operational problems in distribution network due to intermittent characteristic of the renewable energy sources while providing numerous other benefits such as ancillary services, peak reduction, and reliability improvement. The widespread adoption of electric vehicles that use battery energy storage could potentially offer a major new means of storing grid electricity too. An overview of energy storage technologies is summarized in Figure 9. (IEA, 2014; Baxter, 2006).

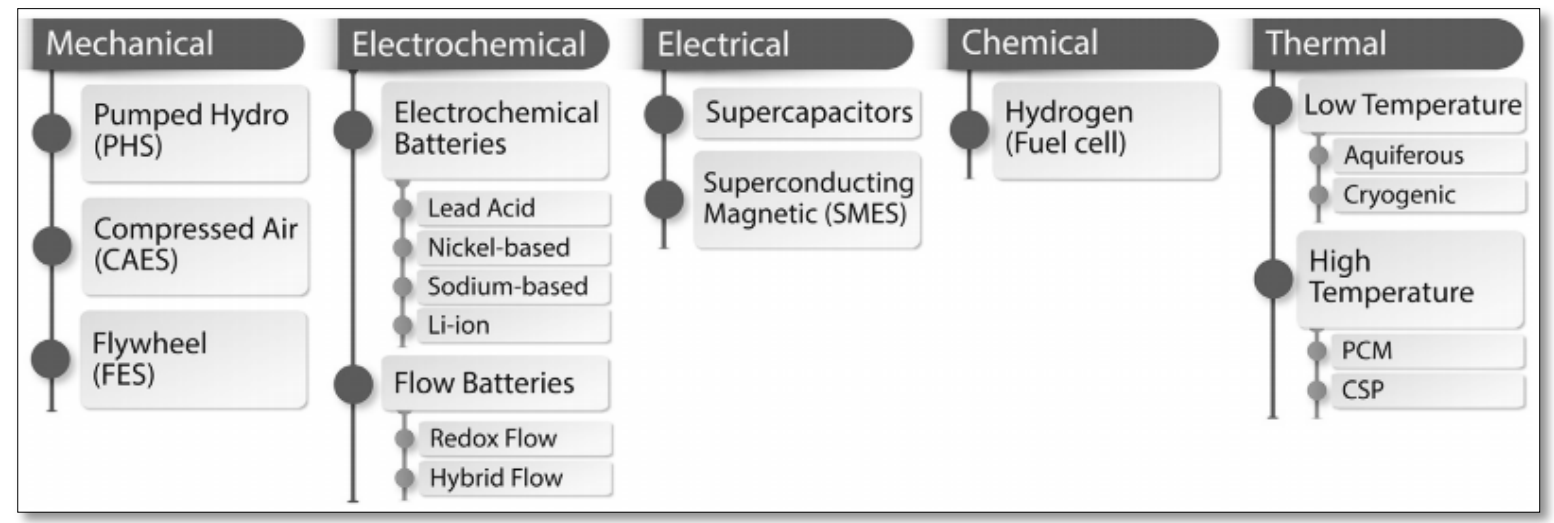

Source: Author's own creation.

Fig. 9 Classification of energy storage technologies by the form of stored energy.

Table 2.

Comparison of various non - renewable DG technologies

\begin{tabular}{|c|c|c|c|c|}
\hline Characteristic & Reciprocating Engines & Micro - turbine & $\begin{array}{c}\text { Combustion Gas } \\
\text { Turbine }\end{array}$ & Fuel Cell \\
\hline Size/Module (kW) & $\begin{array}{c}\text { Gas: } 50 \mathrm{~kW}-5 \mathrm{MW} \\
\text { Diesel: } 20 \mathrm{~kW}-10 \mathrm{MW}\end{array}$ & $30-200$ & $1-20,000$ & $50-1000+$ \\
\hline Electrical Efficiency (\%) & $\begin{array}{c}\text { Gas }-31-42 \\
\text { Diesel }-26-43\end{array}$ & $25-30$ & $21-40$ & $35-54$ \\
\hline Overall Efficiency (\%) & $\begin{array}{c}\text { Gas }-80-89 \\
\text { Diesel }-85-90\end{array}$ & $\sim 80-85$ & $\sim 80-90$ & $\sim 80-85$ \\
\hline Installed Cost $(\$ / \mathrm{kW})$ & $\begin{array}{c}\text { Gas }-250-600 \\
\text { Diesel }-125-300\end{array}$ & $250-600$ & $300-600$ & $360-1000$ \\
\hline Total Maintenance Cost (US\$/ MWh) & $\begin{array}{c}\text { Gas }-7-15 \\
\text { Diesel }-5-10\end{array}$ & $5-10$ & $3-8$ & $5-10$ \\
\hline $\begin{array}{l}\mathrm{CO}_{2} \text { emissions }(\mathrm{kg} / \mathrm{MWh}) \text { in non }-\mathrm{CHP} \\
\text { mode }\end{array}$ & $\begin{array}{l}\text { Gas }-500-620 \\
\text { Diesel }-650\end{array}$ & 720 & $580-680$ & $430-490$ \\
\hline $\mathrm{NO}_{x}$ emissions (kg/MWh) & $\begin{array}{c}\text { Gas }-0.2-1.0 \\
\text { Diesel }-10\end{array}$ & 0.1 & $0.3-0.5$ & $0.005-0.01$ \\
\hline $\mathrm{SO}_{2}$ emissions $(\mathrm{kg} / \mathrm{kWh})$ & $\begin{array}{c}\text { Gas }-1.25 \\
\text { Diesel }-0.032\end{array}$ & 0.037 & 0.032 & $\mathrm{NA}^{*}$ \\
\hline Peak Shaving & Yes & Yes & Yes & Yes \\
\hline Reliability & Yes & Yes & Yes & Yes \\
\hline Power Quality & Yes & Yes & Yes & Yes \\
\hline Green Power & No & No & No & No \\
\hline
\end{tabular}

NA* - Not Available, Source: [Bansal, 2017]

Integrating storage into evolving energy systems is a key challenge that is least well - understood because there is currently no energy model that can fully represent the benefits of different types of energy storage across an energy system. There are a number of economic, social, and regulatory barriers to energy storage deployment. The capital costs of most energy storage technologies are thought to be too high to justify their deployment at present and there is a need for innovation to reduce these costs. Public acceptance of storage technologies is important but has received little investigation. There is a need to find the most appropriate roles for different storage technologies, based on the value that each technology offers and taking into consideration barriers to each technology. A detail comparison of previously discussed non - renewable DG technologies is tabulated in Table 2.

\subsection{Renewable Based DG Technologies}

3.2.1 Solar Photovoltaic Cell Energy Source: Photovoltaic (PV) systems involve the direct conversion of sunlight into electricity with no intervening heat engine. PV devices are solid state; therefore they are rugged and simple in design and require very little maintenance. A key advantage of 
PV systems is that they can be constructed as either gridconnected or stand-alone to produce outputs from microwatt to megawatts. They have been used as the power sources for calculators, watches, water pumping, remote buildings, communications, satellites and space vehicles, as well as megawatt-scale power plants. Because they are light in weight, modular, and do not require gaseous or liquid fuel supply, PV fit a niche that is unavailable to other DG technologies. The working principle of solar PV cell is demonstrated in Figure 10 (Labouret and Villoz, 2010).

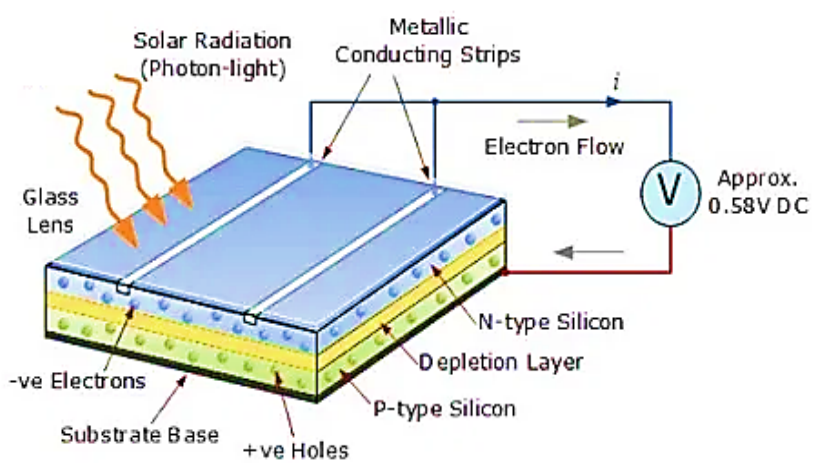

Source: [Florensa and Cueva, 2003]

Fig. 10 Solar PV Cell Working principle

PV systems are now commercially available in rooftop small sizes (less than $10 \mathrm{~kW}$ ), medium size $(10-100 \mathrm{~kW})$ and large systems above $100 \mathrm{~kW}$ connected to distribution system feeders. PV can be economically favorable when their power availability during the peak load periods and reliability is an important factor in the system. PV is also an efficient DG technology when environmental issues are considered. PV systems can operate grid connected or independent of the grid, and since they use power storage systems and power electronics converters, they can respond to dispatching commands quickly. Most grid connected PV power plants enjoy investment subsidies and financial incentives or favorable prices for the electricity they produce (Gehlot et al., 2016). A $700 \mathrm{kWp}$ grid connected rooftop solar power plant project at Ahmedabad Airport, Gujarat is shown in Figure 11 (GoI, 2018).

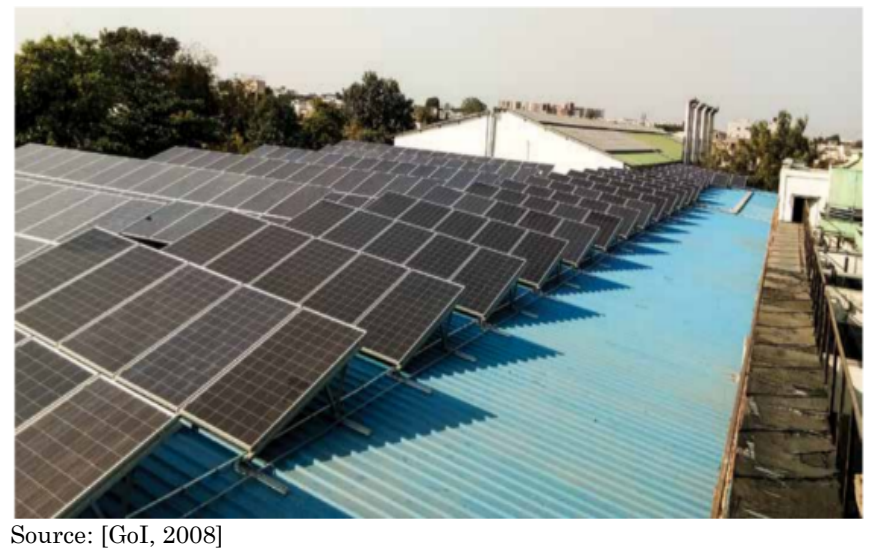

Fig. $11700 \mathrm{kWp}$ Grid Connected Rooftop Power Plant project at Ahmedabad Airport, Gujarat
3.2.2 Wind Power Generation: A wind energy conversion system (WECS) is powered by wind energy and generates mechanical energy that sends energy to the electrical generator for making electricity. The typical layout of a horizontal axis wind turbine is shown in Figure 12 and the block diagram of a WECS is shown in Figure 13 (Brouwer et al., 2016).

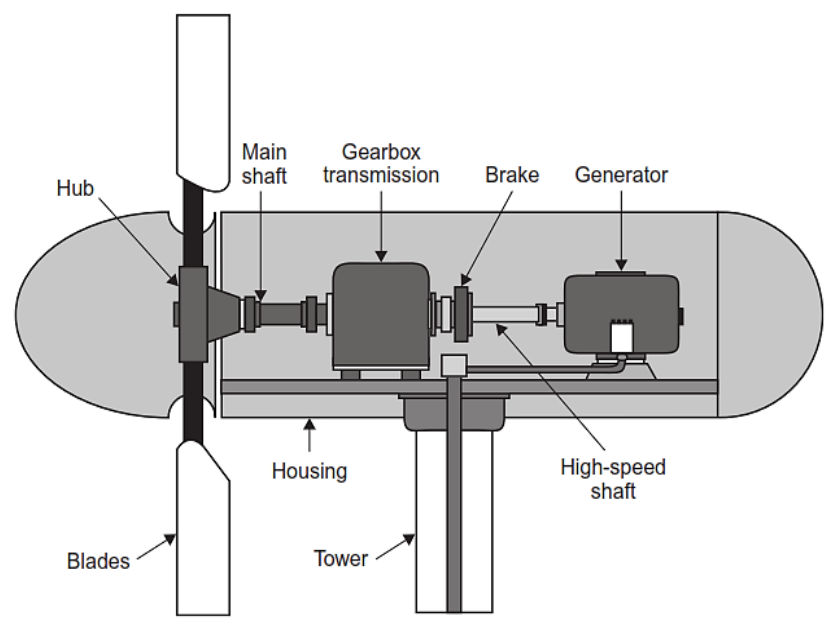

Source: [Afanasyeva et al., 2016]

Fig. 12 Schematic of horizontal axis wind turbine

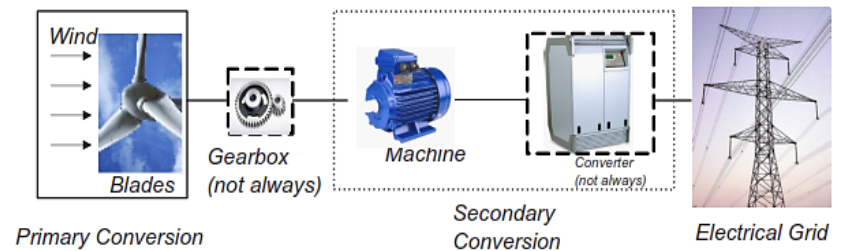

Source: [Engelhardt, 2011]

Fig. 13 Block diagram of WECS

The generator of the wind turbine can be a permanent magnet synchronous generator (PMSG), doubly fed induction generator, induction generator synchronous generator, etc. Wind energy acquired from the wind turbine is sent to the generator. To achieve maximum power from the WECS, the rotational speed of the generator is controlled by a pulse width modulation converter. The output power of the generator is supplied to the grid through a generator-side converter and a gridside inverter. A wind farm can be distributed in onshore, offshore, seashore, or hilly areas. The WECS might be wind energy is an alternative to fossil fuels, it is plentiful, renewable, widely distributed, clean, low cost, produces no emissions during operation, and uses a tiny land area. The effects on the environment are generally less problematic than those from other conventional power sources the most promising DG for future smart grid.

The overall capacity of all wind turbines installed worldwide by the end of 2018 reached 597 Gigawatt. India's wind energy sector is led by indigenous wind power industry and has shown consistent progress. The expansion of the wind industry has resulted in a strong ecosystem project operation capabilities and 
manufacturing base of about 10,000 MW per annum. The country currently has the fourth highest wind installed capacity in the world with total installed capacity of 37.27 GW (as on 31st December 2019) and 62 Billion Units were generated from wind power during 2018-19.

3.2.3 Biomass Generation: Biomass power plants can generate electricity using a steam cycle where biomass raw materials such as waste are converted into steam in a boiler. The resulting steam is then used to spin a turbine which is connected to a generator. Alternatively, biomass materials can be converted to biogas. This biogas can be cleaned and upgraded to natural gas standards when it becomes bio-methane. The biogas can be used in gas turbines, piston-driven engines or fuel cells to generate electricity. The advantage is that as a renewable energy source, biomass-based power plants produce low emission and mitigates global warming. Biomass materials used for power generation include bagasse, rice husk, straw, cotton stalk, coconut shells, soya husk, de-oiled cakes, coffee waste, jute wastes, groundnut shells, saw dust etc. (Bond and Templeton, 2011). Over 500 biomass power and cogeneration projects with aggregate capacity of 9946.11 MW have been installed in India up to November 2019 (GoI, 2018).

A schematic of a modern biomass power plant is shown in Figure 14.

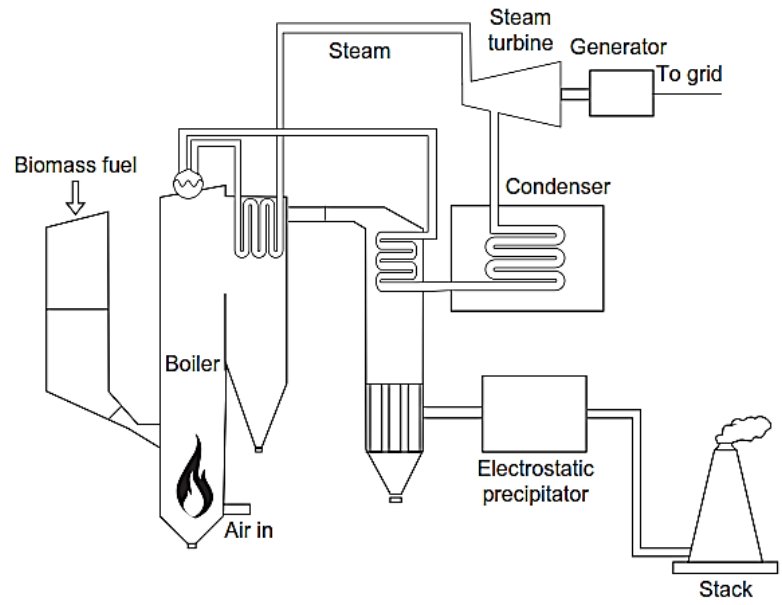

Source: [Bond and Templeton, 2011]

Fig. 14 Schematic of a direct-fired biomass power plant

3.2.4 Small Hydro Power (SHP): The gravitational force of water falling from a raised level to ground level can be efficiently converted to electric energy. This form of electricity generated from hydropower is called as hydroelectricity. Hydropower is a source of renewable energy, and its small-scale applications can be used for distributed generations. This form of electricity generation has been implemented since the nineteenth century. William George Armstrong developed the very first practical hydroelectric system in 1878 in England. The first small hydro power plant installed in India was in Darjeeling in 1897 with a capacity of $130 \mathrm{~kW}$. A typical conventional small hydro power plant (SHP) is depicted in Figure 15 (GOI, 2018). Further, therevis no globally accepted definition of SHP and asjsuch different countries have defined different capacity limits for SHP (see Table 3).

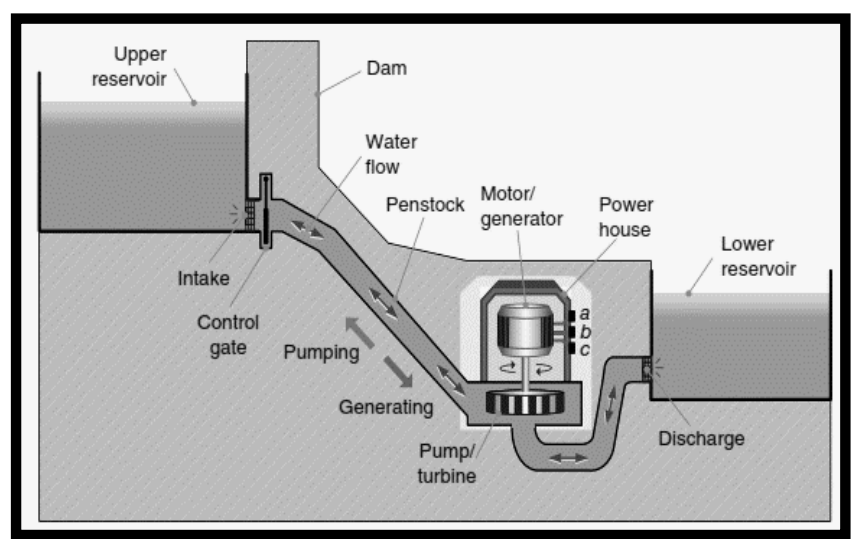

Source: [vanVuuren et al., 2014]

Fig. 15 A conventional small hydro power plant

Table 3.

SHP definition and classification in some selected countries

\begin{tabular}{cccc}
\hline Country & $\begin{array}{c}\text { Micro } \\
(\mathbf{k W})\end{array}$ & $\begin{array}{c}\text { Mini } \\
\mathbf{( k W )}\end{array}$ & Small (kW) \\
\hline Brazil & $<100$ & $101-1000$ & $1001-30,000$ \\
China & $\leq 100$ & $\leq 2000$ & $\leq 50,000$ \\
Philippines & - & $51-500$ & $<15,000$ \\
Sweden & - & - & $101-15,000$ \\
USA & $<500$ & $501-2000$ & $<15,000$ \\
India & $<100$ & $<2000$ & - \\
Japan & - & - & $<10,000$ \\
Nigeria & $\leq 500$ & $501-2000$ & - \\
France & $<500$ & $501-2000$ & $<50,000$ \\
New Zealand & - & $<10,000$ & $<50,000$ \\
United Kingdom & $<1000$ & - & - \\
Canada & - & $<1000$ & $1001-1,500$ \\
Russia & - & - & $<30,000$ \\
Norway & $<100$ & $101-1000$ & $1000-10,000$ \\
Germany & $<500$ & $501-2000$ & $<12,000$ \\
Turkey & $<100$ & $101-2000$ & $<10,000$ \\
\hline
\end{tabular}

Source: [Ferreira et al., 2016]

The SHP projects do not encounter the problems associated with large hydel projects of rehabilitation and resettlement and do not disturb the ecological balance of the areas. These projects have potential to meet power requirements of remote and isolated areas in a decentralized manner besides providing employment opportunity to local people. The cumulative installed capacity of SHP in India as on 31st November 2019 is 4647.56 MW.

Table 4 shows the comparison of various renewable DG technologies. 
Table 4

Comparison of various renewable DG technologies

\begin{tabular}{|c|c|c|c|c|}
\hline Characteristic & $\begin{array}{l}\text { Solar Photovoltaic } \\
\text { System }\end{array}$ & $\begin{array}{l}\text { Wind Power } \\
\text { Generation }\end{array}$ & $\begin{array}{c}\text { Biomass Power } \\
\text { Generation }\end{array}$ & Small / Micro Hydro \\
\hline Size/Module (kW) & $1-20$ & $200-3000$ & $100-20,000$ & $\begin{array}{c}\text { Small - } \\
1000-100000 \\
\text { Micro }-25-1000\end{array}$ \\
\hline Electrical Efficiency (\%) & $6-15$ & Not Applicable & $15-25$ & Not Applicable \\
\hline Overall Efficiency (\%) & $\sim 40-45$ & $35-45$ & $\sim 60-75$ & $60-90$ \\
\hline Installed Cost $(\$ / \mathrm{kW})$ & $\sim 5000-7000$ & $900-1400$ & $2000-3500$ & $30-250$ \\
\hline $\begin{array}{l}\text { Total Maintenance Cost } \\
\text { (US\$/ MWh) }\end{array}$ & $\sim 1-4$ & 10 & $\mathrm{NA}^{*}$ & $0.045-0.09$ \\
\hline $\begin{array}{c}\mathrm{CO}_{2} \text { emissions }(\mathrm{kg} / \mathrm{MWh}) \text { in } \\
\text { non - CHP mode }\end{array}$ & No Direct Emissions & No Direct Emissions & $\mathrm{NA}^{*}$ & $\begin{array}{l}\text { Small - } 10-12 \\
\text { Micro }-16-20\end{array}$ \\
\hline $\mathrm{NO}_{\mathrm{x}}$ emissions $(\mathrm{kg} / \mathrm{MWh})$ & No Direct Emissions & No Direct Emissions & $\mathrm{NA}^{*}$ & $\begin{array}{l}\text { Small }-0.046-0.056 \\
\text { Micro }-0.071-0.086\end{array}$ \\
\hline $\mathrm{SO}_{2}$ emissions $(\mathrm{kg} / \mathrm{kWh})$ & No Direct Emissions & No Direct Emissions & $\mathrm{NA}^{*}$ & $\begin{array}{l}\text { Small }-0.024-0.029 \\
\text { Micro }-0.038-0.046\end{array}$ \\
\hline Peak Shaving & No & No & No & No \\
\hline Reliability & No & No & No & Yes \\
\hline Power Quality & No & No & No & Yes \\
\hline Green Power & Yes & Yes & Yes & Yes \\
\hline
\end{tabular}

\section{DG Growth Drivers}

The primary drivers behind the growth of DG and the current focus on its integration into electric power system operation and planning can be classified into three main categories, namely environmental, commercial, and national or regulatory (Pepermans et al., 2005; Paliwal et al., 2014). These drivers are now discussed briefly below.

\subsubsection{Environmental Factors}

- The use of renewable energy and CHP to limit greenhouse gas (GHG) emissions is one of the main drivers for DG. In this regard, it is important to point out that integration of renewable sources of electrical energy into power systems is a somewhat different question from that of the integration of DG into power systems. Integration of DG includes some of the issues related to integration of renewable sources but clearly does not deal with integration of transmission connected renewable sources such as large on shore and offshore wind farms.

- Another important factor for DG from the environmental perspective is the avoidance of construction of new transmission lines and large power plants for which there is increasing public opposition. There is, however, opposition also from some environmental lobby group to onshore wind farms on grounds of noise and visual "pollution". There is therefore a balance to be struck between the need for sustainable energy solutions on the one hand and the need to maintain scenic beauty of the environment. Some argue that environmentally benign technologies such as wind that do not emit any GHG and have no long term waste management problems should be favoured.

Technological developments in generator technology are already delivering cost-effective small to mediumsized generation technologies for domestic applications such as micro-CHP.

\subsubsection{Commercial Factors}

- One of the acknowledged consequences of the introduction of competition and choice in electricity is the increased risk faced by all players in the electricity supply chain from generators through transmission and distribution businesses to retailers. It is well known that the capital outlay required to establish new power stations can be very high. The uncertainties associated with a competitive market environment may favour generation projects with a small capacity whose financial risk is commensurately small.

- The presence of DG close to load centers can have a beneficial impact on power quality (PQ) and supply reliability. One area of improvement is voltage profile improvements, reduction in the number of customer minutes lost, especially if DG is allowed and able to stay on when there are network outages (islanding).

\subsubsection{National / Regulatory Factors}

- In recent times, there has been increasing concern among energy policy makers regarding energy security. There is a recognition that modern societies have become dependent on energy resources to the extent that, should there be a disruption in its supply the consequences would be 
too ghastly to contemplate in political, economic, and social terms. Because of this, the policy makers focusses on energy security and sustainability. In the context of energyt ecurity and sustainability, DG is an attractive proposition in many respects.

- There is an abiding faith among the proponents of reform of electricity supply industries that introduction of competition in generation and customer choice will deliver low energy prices and better service quality. One of the prerequisites for effective competition to occur is that there must be many players in the market. DG clearly advances this cause by providing many small generators that could potentially trade in the energy market and where appropriate market arrangements exist, also trade in ancillary services.

\section{Major Issues with Grid Integration}

Conventionally, power generation, transmission, distribution and load demands have been managed as independent processes. Due to the large amount of DGs in the power network, the traditional approach of the power system management has gradually been shifting. DGs are a vital part of the modern smart power system but integration of DGs in the conventional power network is challenging for the power system engineers.

DG may have positive and negative impacts on the transmission and distribution system. Because of the direct connection of DG to the distribution system, impacts are expected to be most prevalent at the distribution level. Many of the impacts of DG are attributable to the fact that the grid was not originally designed to accept generation on the distribution system. The impact of DG integration has to be carefully investigated in order to ensure optimum system performance.

As suggested by Soroudi et al. (2011), distribution networks have been designed to handle unidirectional power flow. Thus integration of distributed generation can result in voltage issues, problems in protection co-ordination, handling of reactive power and power quality issues. Further, if solar and wind based DGs are integrated; their stochastic nature can raise concerns regarding reliability of supply. High financial cost associated with RES based DGs can restrict their deployment on large scale. Lopes and Borges (2015) have classified DG integration issues into three categories viz. Technical, Commercial and Regulatory. Commercial and regulatory issues are affected by government policies and societal conditions and are not the focus of this review. In addition to all of the issues mentioned above, the size and geographic location of a DG system are also important factors that may affect its impact on the transmission and distribution grid. The technical issues are now discussed in turn below.

- Impact on Voltage Magnitude Variations (i.e. Voltage Regulation): Maintaining a proper voltage level is important for the correct operation of the apparatus or components connected to the electric power system. In passive distribution feeders the power flow changes due to a changing demand. Now-a-days, in distribution grids DG is integrated and provides electric power close to the load. The integration of DG can significantly change the power flow in the distribution feeder and hence affect the feeder voltage.

The impact of DG on voltage control is depending on the power flow in the network. The voltage profile is not violated when the injected power by DG is less or near the load of the feeder and the power factor of the DG is in line with the power factor of the load. In this case the energy supplied by the grid is decreasing as well as the current through the feeder. This results in a reduced voltage drop. However, when the generated power exceeds the load of the feeder or the power factor is extreme, voltage rise occurs. This voltage rise is due the reversed power flow and is a function of the size of DG, the power factor and the impedance of the grid. The voltage fluctuation may lead to voltages outside acceptable ranges imposed by the regulatory authorities. Fluctuation in voltage can cause wear and tear to electrical equipment owned by customers and utilities, and is viewed as a negative impact that DG systems can have on the distribution system. Some mitigation approaches, for example load tap changers on transformers can be used to mitigate voltage issues (Mahmud et al., 2014; Mahmud and Zahedi, 2016).

- Impact on System Line Losses: Transporting electrical power causes losses in the transmission and distribution grid. The power losses in a line can be calculated using Ohm's law. If a line is carrying a current, the power losses in a line can be calculated with equation

$$
P_{\text {Loss }}=\frac{1}{T} \int_{0}^{T} i(t)^{2} R d t
$$

Considering a sinusoidal current, $i(t)=I_{\max } \sin \omega t$, the average power loss, $P_{\text {Loss }}$ over a complete cycle $(T=2 \pi)$ is calculated as:

$$
P_{\text {Loss }}=\frac{1}{2 \pi} \int_{0}^{2 \pi}\left(I_{\max }^{2} \sin ^{2} \omega t\right) \times R d \omega t
$$

which on simplification gives,

$$
P_{\text {Loss }}=I^{2} R \text { watt }
$$

Where $\mathrm{P}_{\text {Loss }}$ is the average power loss in the line, I is rms the current through the line and $R$ is the resistance of the line. Changing the power flow in the line changes the current through the line and thus the losses are affected. The effect of DG on grid losses strongly depends on the injected power and location in the grid. Connecting DG to a load at a distribution feeder, the injected power of the DG will be consumed by the load and the power flow in the feeder is reduced. In this case the losses are reduced as well. Also, the power flow from higher voltage levels toward the load is reduced. This decreases the risk of overloading at the higher voltage levels. Thus, distributed generation is in general advantageous for overloading and losses.

On the other hand, if a DG system is injecting more power onto the distribution system than conductors were originally designed for, losses could actually increase. Moreover, intermittent generation sources with a weak correlation with the load, such as wind turbines, can have a negative impact on grid losses. Especially during night-time there is low demand and in a high wind situation the distribution grid can start to export power 
whichj ncreases the grid losses. In this case local storage systems can have a positive effect on the grid losses because the storage system can locally balance the power flow and prevents the export of power (Delfanti et al., 2013).

- Impact on Power Quality: Two aspects of power quality are usually considered to be important with distributed generation: (1) transient voltage variations and (2) harmonic distortion of the network voltage. Depending on the particular circumstance, distributed generation plant can either decrease or increase the quality of the voltage received by other users of the distribution network.

Distributed generation plant can cause transient voltage variations on the network if relatively large current changes during connection and disconnection of the generator are allowed. The magnitude of the current transients can, to a large extent, be limited by careful design of the distributed generation plant although for single, directly connected induction generator won, weak systems the transient voltage variations caused may be the limitation on their use rather than steady-state voltage rise. Synchronous generators can be connected to the network with negligible disturbance if synchronized correctly and anti-parallel soft-start units can be used to limit the magnetizing inrush of induction generators to less than rated current. However, disconnection of the generators when operating at full output may lead to significant, if infrequent, voltage drops. Also, some forms of prime mover (e.g. fixed speed wind turbines) may cause cyclic variations in the generator output current, which can lead to so-called flicker nuisance if not adequately controlled.

Inverter-connected DG-units might cause harmonics. The magnitude and the order of the harmonic currents depends on the technology of the converter and the mode of operation. Although, with recent technology with fast switching components used to compose the input waveform, this problem is not that acute anymore. Although the injection of harmonic currents can distort the voltage waveform which can propagate throughout the distribution grid. Apparently small voltage distortions can cause large harmonic currents at a resonance condition (the large capacitance of extensive cable networks or shunt power factor correction capacitors may combine with the reactance of transformers or generators to create resonances close to the harmonics frequencies produced by the power electronic interfaces) and have to be prevented. An ability to reduce the harmonic current injection is filtering of the output current. Modern power electronic converters are able to filter the injected current and reduce the injected harmonics (Latran et al., 2015; Bizon, 2018).

- Impact on Fault Level and Protection: The connection of DG to the distribution grid changes the fault level. The impact on the fault level depends on the ability of the DG-unit to contribute to the fault current. The contribution to the fault current strongly depends on the interface between the grid and the DG unit. Inverter coupled DG hardly contribute to the fault current while directly connected DG do contribute to the fault current. The contribution to the fault current can be such that the equipment rating is exceeded. In that situation limitation of the fault current is necessary (Brearley and Raja Prabu, 2017).

A significant contribution to the fault current of the DG-unit affects the protective systems in the distribution grid. Because the fault currents are affected by the DGunits, the measured currents used for protection purposes, are affected as well. This can lead to incorrect operation of the protective system and causes fault detection problems and selectivity problems. Hence integration of DGs requires protection co-ordination capable of sustaining bidirectional power flows (Ishchenko et al., 2012)

- Impact on Peak Demand Reduction: To the extent DG output is correlated with local loads, DG may reduce the peak load on some parts of the distribution system. The amount of peak demand reduction will depend on the type of DG resource, its operating pattern, and the load profile for the feeder or substation. Peak demand reduction is generally viewed as a positive impact as it reduces the required capacity and equipment for the system (Paliwal et al., 2014).

- Impact on Frequency Control: The Regulatory authorities and IEEE standards provide frequency requirements for DG connecting to the distribution system. These requirements provide the upper and lower limits for the frequency of the DG system. When the frequency goes outside of the specified range, the DGisystems will automatically be tripped offline.

Energy generating technologies that have inertia, such as combustion turbines, provide frequency support meaning they can help adjust the frequency of the grid. This can be done by either speeding up or slowing down the rotation of the devices. The most prevalent DG technologies, suchtas solar PV, do not provide frequency support. In fact, these systems are required to trip offline in the event of an over or under frequency situation. The net effect of DG systems tripping offline could, in the future when higher penetration is achieved, exacerbate an under frequency situation; this is viewed as a negative impact of DG (Mahat et al., 2010).

Changes to inverter standards (specifically IEEE 1547), such as allowing a wider range of voltage and frequency conditions, could help alleviate challenges with inadvertent voltage and frequency trips. Smart inverters could also help mitigate the frequency impact of DG. Smart inverters may be able to provide frequency support, or avoid tripping offline during some under/over frequency events (IEEE, 2003).

- Impact on stability and fault - ride through: Until recently distribution grids were more or less passive grids with a uni-directional power flow from the transmission grid towards the distribution grid. At this moment grid operators connect DG in a 'fit and forget' fashion, however, when the penetration level is increasing this is no longer acceptable. Then DG will displace a significant part of the power produced by the central power plants which affects the overall behavior of the power system. (Paliwal et al., 2014) discussed that the replacement of central power plants by DG leads to a reduction of the available inertia in the power system which can cause stability problems for a penetration level larger than $30 \%$. However, this value strongly depends on the boundary conditions of the power system. 
So, having sufficient rotating inertia in the power system is important for stable operation during a large unbalance between load and generation. However, replacing central power plants by DG not only reduces the available inertia but it can even increase the unbalance between load and generation during transmission grid faults. This is caused because of the disconnection of DG during the transmission grid disturbance. The reduction of the rotating inertia and the disconnection of a large amount of DG can jeopardize the stability of the power system.

To mitigate the effect of DG on power system stability grid operators have defined fault ride-through criteria for DG. These criteria were already set for central power plants but now also become operational for DG connected to distribution grids. Fault ride-through criteria define for what voltage dips with a certain duration the DG have to stay connected to the grid. Depending on the size of the DG-unit, the fault ride-through criteria can also oblige additional grid support such as voltage and frequency support, during and after a disturbance. Keeping DG during a local disturbance connected to the grid canicause interference with the local protective system. As a consequence, the interference of DG with the protective system can lead to no or delayed fault clearing or exceeding the stability limit of the DG-units. With the increasing integration of $\mathrm{DG}$ in distribution grids coordination between local protective systems and fault ride through criteria becomes more and more important and has to be studied thoroughly to maintain safe and secure operation of the distribution grid with DG-units.

- Operational Flexibility: AsjDG penetration increases, the complexity of the distribution system increases and utilities may have less flexibility to operate their system, potentially negatively impacting the system. DG brings additional complexity to the operation and troubleshooting of the distribution system for many reasons, including the fact that the interconnection point may act as a generation source or a load. Furthermore, when problems occur on the distribution system, it may be more difficult to troubleshoot them. For these reasons, it is likely that utilities will have less flexibility with their system. For example, many distribution systems are radial in nature, which means there is a long line running from the source, and no loops or redundancy. If a DG system causes an issue with the distribution system somewhere along this line, requiring a portion of the line to be isolated, then the utility may have to disconnect the DG system and anything beyond it from the main source. This limition operational flexibility may reduce the reliability of the distribution system in some cases (Roy and Pota, 2015).

- Reliability Issues: The amount of power that a renewable source of energy such as solar and wind can produce depends on availability of sun and wind. As sun radiation and wind speed are never constant, therefore the output power of a solar energy system or a wind power will never be constant. Hence, high penetration of renewable energy DG into a power network can result in risk of making the entire network less reliable (Khalesi et al., 2011).

- Location and Size Dependent Impact of DG: Penetrating embedded generation, or distributed generation (DG), in power distribution grids presents great benefits and substantial positive social impacts to utilities, system operators and electricity consumers. However, DG may degrade the performance of the distribution system, if it is not planned carefully. In other words, if the location and size of DGs are not properly determined, losses in the distribution system will increase significantly, and also the voltage profile of the distribution network will be polluted (or distorted). In order to achieve the benefits presented by installing DG in distribution network, optimal planning of DG units are essential. Under optimal planning of DG, determination of its optimal size and location is the most notable and promising aspect to avail the prospective benefits.

The advantages of an optimal sitting and sizing of distributed generation in a distribution network are many. First, an optimal sitting of the available generation resources will increase the security and reliability of the system. Secondly, by planning the optimal locations for technologies like wind and solar power, it is possible to maximize its penetration in the system, thereby minimizing not only the costs of electricity supply, but also secondary objectives like minimization of $\mathrm{CO}_{2}$ emissions. Thirdly, an optimal sitting of the electricity generation portfolio will require of smaller capital expenditures on power lines. Fourthly, distributed generation capacity can contribute to the enhancement of the overall system efficiency, by for example reducing power losses in the network by producing closer to the demand (Roy and Pota, 2015). Most of the existing work on DG siting and sizing considered various issues, such as power loss minimization; voltage profile; stability; reliability; and loading margin improvement; harmonic pollution reduction; investment minimization or profit maximization; loading margin etc., by formulating single or multi-objective problems. The impacts of DG allocation on the performance of distribution system are mentioned in Table 5.

Table 5 .

Impacts of DG allocation on Distribution System

\begin{tabular}{ccc}
\hline Type of Impact & $\begin{array}{c}\text { Non }- \\
\text { Renewable } \\
\text { DG }\end{array}$ & $\begin{array}{c}\text { Renewable } \\
\text { DG }\end{array}$ \\
\hline Environmental & - & $\checkmark$ \\
Voltage Stability & $\checkmark$ & $\checkmark$ \\
Reverse Power Flow & $\checkmark$ & $\checkmark$ \\
Reliability & $\checkmark$ & -- \\
Deferring Upgrades of Power & $\checkmark$ & $\checkmark$ \\
System & $\checkmark$ & $\checkmark$ \\
Reduction of Electricity Tariff & - & $\checkmark$ \\
Reduction of GHG & $\checkmark$ & $\checkmark$ \\
Cost Saving & $\checkmark$ & $\checkmark$ \\
DG Allocation Flexibility & $\checkmark$ & $\checkmark$ \\
Loss Minimization & $\checkmark$ & $\checkmark$ \\
Safety & $\checkmark$ & $\checkmark$ \\
Islanding & $\checkmark$ & -- \\
Voltage & $\checkmark$ & $\checkmark$ \\
Stiffness in Distribution Bus & & \\
\hline
\end{tabular}

Source: Author's own creation 


\section{Potential Benefits of DG Deployment}

The deployment of distributed generation (DG) in power distribution networks is gaining more acceptances since DG units can bring multiple benefits to distribution network while supplying energy sales as a primary task. The benefits that can be achieved by deploying DGs to distribution networks can be classified into three major categories: economic, technical and environmental benefits (Akella et al., 2009).

In addition, DG units can participate into the competitive market to provide ancillary services such as spinning reserve, voltage regulation, reactive power support and frequency control. The DG planning studies must take into consideration the benefits that DGs can offer since these benefits can only be realised by selecting the optimal placement, size, DG technology type and volume within the network. However, inappropriate or sub - optimal planning can have negative impacts on the performance of distribution network. Thus, it becomes imperative to discuss the benefits of DG (Jain et al., 2017; Zahedi, 2011; Chiradeja and Ramakumar, 2004).

\subsubsection{Technical Benefits}

- Should System Loss Reduction: DG units are usually installed near the load site on the radial distribution networks. Thus, part of the transmission power is replaced by the injected DG power causing a reduction in transmission and distribution line losses.

- Voltage Profile Improvement: The injection of real power and the injection or consumption of reactive power by DG units improve system voltage profiles and the load factor. It must be mentioned that the amount of improvement depends on the sitting and sizing of DG units.

- Inherently enhance system stability, supply the spinning reserve required.

- Enhances Power Quality (i.e. Reduce flicker and harmonic distortion): DG equipped with a power inverter interface can be used to alleviate power quality problems present on the $\mathrm{AC}$ grid by independently controlling the real and reactive components of the power injected into the ac grid. Under these conditions, the distributed generator can be configured to behave as an active power conditioner or compensator by injecting reactive power to regulate the voltage at the point of coupling, regulate the total plant power factor, or to mitigate voltage flicker. The power inverter can also correct voltage sag, but the rating of the inverter may have to be significantly increased to fulfill this function.

With properly designed and implemented power electronics interface, connection of DG to the grid could theoretically cancel grid distortions and help regulate voltage, and minimize harmonics.

- $\quad$ Enhanced System Reliability: DGs can contribute significantly in the reliability and service continuity since there many different generation plants across the power system in contrast to the very few large centralized generation units. This can be extremely useful for consumers that require the highest possible reliability no matter if they have to pay for higher service costs.

- Improvement of Security Supply: The increasing penetration of DG and future intelligent networks (smart grid) can contribute to increasing security supply, as it will diversify the primary energy supplies and potentially reduce the dependency for foreign sources.

- Increased overall energy efficiency: The use of combined heating and power (CHP) units allows the simultaneous generation of heat and electricity and hence improvement in energy efficiency average of the system.

- Relieved Transmission and Distribution Congestion: Energy storage systems can be used to diminish congestion in the transmission and distribution system. On the distribution side, energy storage can be used to avoid over-sizing network lines to meet the maximum demand at any time. On the transmission side, energy storage can be employed to reallocate demand to a period when the system is not capacityconstrained, thus shaving off the peak of the system load and avoiding transmission congestion.

- Network Upgrade Deferral: The network upgrade deferral is the ability to defer the required investment on reinforcing feeders and transformers due to DG integration. Since DG is connected near to the loads, low and medium levels of distributed energy resources (DERs) reduce the power flow coming from the main grid. This generation helps to offset peak demand and load growth. The demand reduction postpones the necessity for network upgrades (distribution lines and transformers mainly).

- Reduction in Peak Power Requirements: Installation and use of DG systems by customers and/or utilities can produce reductions in peak load electricity requirements, depending on how the DG is operated. Operation of DG that reduces peak loads on a substation will always provide some benefits, whether by decreasing the required maintenance, increasing equipment lifetime, or actually deferring $\mathrm{T} \& \mathrm{D}$ and generating system capacity expansion.

- Provision of Ancillary Services: Ancillary services are essential for a reliable electric delivery system. DG can be used to provide ancillary services, particularly those that are needed locally such as reactive power, but also those that contribute to the reliable operation of the entire system, such as back-up supplies and supplemental reserves.

A small number of studies have explored the value proposition of using DG for ancillary services and these have found that there is potential for DG to cost effectively contribute to the provision of ancillary services.

- Reduces Vulnerability of Distribution Grid to Terrorism and Provides Infrastructure Resilience: DG can improve resilience through its reliance on larger numbers of smaller and more geographically disperse power plants, rather 
than large, central station power plants and bulkpower transmission facilities. Recent examples from nearly every area of critical infrastructure as defined by Department of Homeland Security (DHS) U.S. verify that DG is a viable means for reducing vulnerability to terrorism and improving the resilience of electrical infrastructure. This is based on actual cases in which DG continued to provide power to critical facilities during times of large-scale power disruptions and outages. These types of outages closely resemble the potential effects of a terrorist attack, one that could be directed at the grid and its components to maximize the loss of power delivery capability. A resilient grid can avert many types of losses, be they economic, material, or information, or losses of human life, health, safety, and communication.
- DG technology is available in a wide capacity range (i.e., from $3 \mathrm{~kW}$ up to $50 \mathrm{MW}$ ), giving the possibility to DG units to be easily installed on distribution networks, both medium and low voltage.

- DG units require a short period of time to install and pose less of an investment risk due to their modular characteristics, which enables them to be easily, assembled anywhere. Each DG unit is totally independent of the others, can generate electricity immediately after its installation and cannot be affected by other units' operation failure.

- DGs can be used as on-site standby to supply electricity in case of emergency and system outages (provide local reliability).

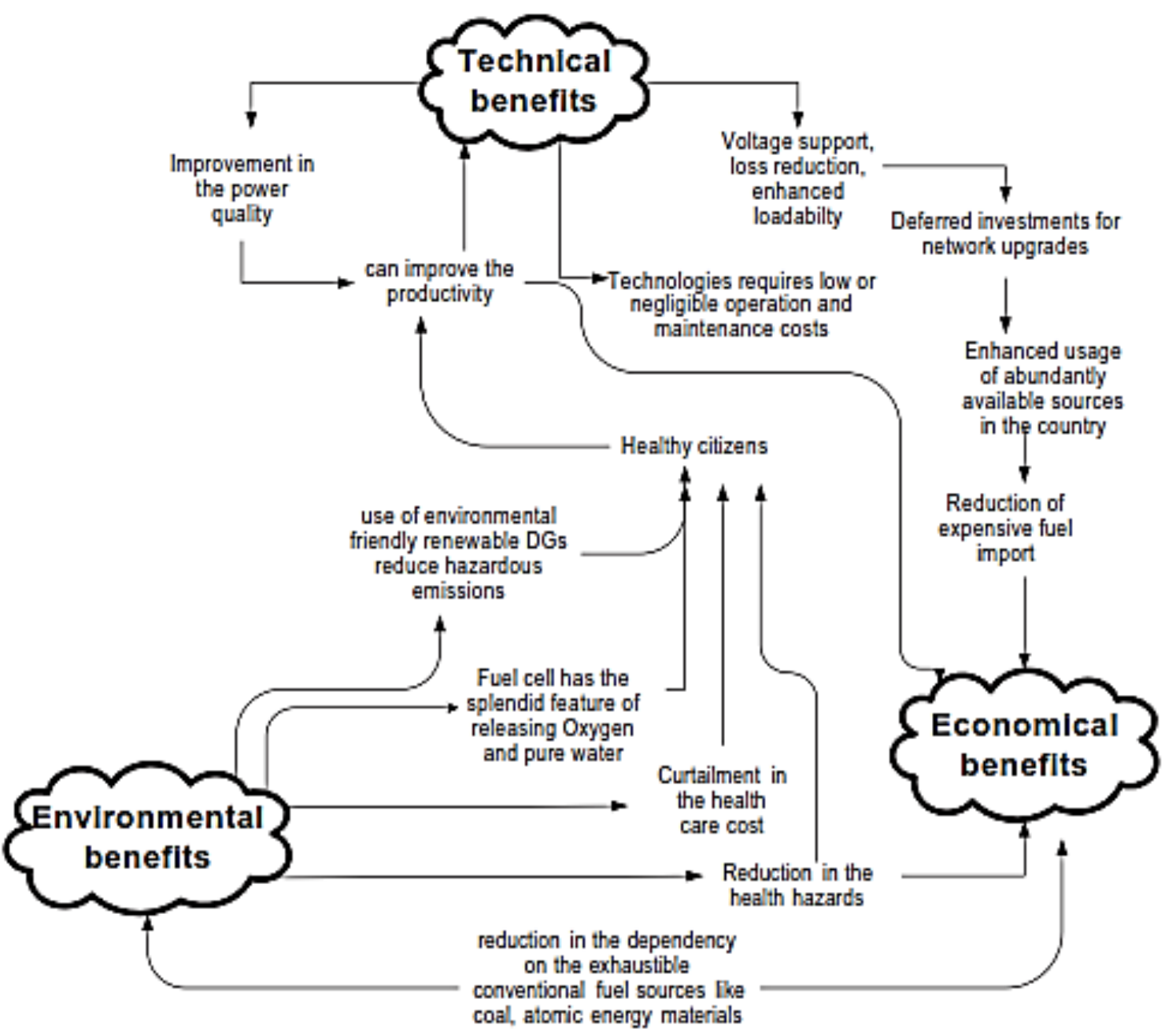

Source: [Jain et al., 2017]

Fig. 16 Alliance of DG Benefits 


\subsubsection{Economic Benefits}

- Reduction of operative cost: Cost reduction in transmission and distribution of energy, hence reduction in losses; and reduction in maintenance costs (failures and lines congestion).

- Reduction of capital costs: DG can delay the need for investments in new transmission and distribution infrastructures and reduce depreciation costs of fixed assets in networks.

- Reduction of environmental costs: Reduction of emissions into the atmosphere helps to reduce associated costs with environmental penalties.

- Electricity tariff reduction: The increased penetration of DG can open energy markets to new agents and low prices.

- Liberalization of energy markets: By allowing market agents to install their own energy generation equipment they can respond to changing market conditions, increasing the flexibility of the system and promoting competitiveness, which can lower the overall prices.

- Deferred investments for generation, transmission, or distribution upgrades.

- Lower operating costs due to peak shaving.

- Reduced fuel costs due to increased overall efficiency.

- Improvement in the power quality will reduce the hazardous situations, which often dwindle on heavy machineries of industries and thus can improve the productivity.

- Reduction of expensive fuel import.

- Curtailment in the health care cost due to environment friendly attribute of renewable DGs.

- Inclusion of technologies in the grid, which requires low or negligible operation and maintenance, costs such as PV plants, fuel cells, biomass etc.

\subsubsection{Environmental Benefits}

- Reduction of fossil fuel consumption: The use of distributed renewable sources and the increased efficiency of multi-generation plants reduce fossil fuel consumption in conventional power plants.

- Reduction in greenhouse gas emission: The reduction of fossil fuel consumption implies the reduction of $\mathrm{SO}_{x}$ and $\mathrm{NO}_{x}$ emissions into the atmosphere.

- Reduced noise pollution due to deployment of low noise technologies.

- More usage of green power

Figure 16 shows that most of these benefits are interlinked

\section{Conclusion}

The wide range of potential applications for distribution generation (DG), decentralization of power system and the trend to use renewable energies in both developed and developing countries suggest that DG may have a large share and potential invpower generation in the future. The introduction of DG units should reduce the pressure on the central power grid principally, but technically speaking, penetration of DG into the power grid creates a new class of concerns or issues different from those found in traditional power sources. These key issues concerning the integration of distributed generation into electric power systems are of most interest to the stakeholders (power system planners and operators, policy makers and regulators, DG developers and customers) in the electrical energy supply industry today. Moreover, with respect to recent technological advancements, enormous benefits can be achieved from distributed generators (DGs) in economical, technical, and environmental fields. The assessment of popularity of benefits help system planners in formulating planning studies more efficiently.

Since the current and future trend of electric power systems is set towards increased integration of DG, particularly renewable energy sources (RES)-based units, a discussion on the relevant aspects related to distributed generation is required to be discussed or addressed. Accordingly, in this paper an extremely critical review has been made that primarily focused on DG definitions, various DG technologies and their current status, key issues pertaining to grid integration (i.e. impacts of DG on the performance of distribution system), drivers of DG growth, and various benefits offered by deployment of DG. These perspectives of DG are of high significance for DG planning studies carried out for the optimal selection, sizing, and placement of DGs in power systems since inappropriate DG location may result in non-optimal use of DG integration, and moreover can have negative impact on system performance in terms of increased losses and degraded voltage profile. Thus, the various discussed viewpoints of DG can help the planning engineers, DG developers, policy makers and regulators to come up with an optimum system planning and enhanced system performance.

\section{References}

Ackermann, T., Anderson, G. and Söder, L. (2001). Distributed generation: a definition. Electric Power Systems Research, 57, 195-204.

Adil, A., M. and Ko, Y. (2016). Social - technical evaluation of decentralized energy systems: a critical review and implications for urban planning and policy. Renewable and Sustainable Energy Reviews, 57, 1025 - 1037.

Afanasyeva, S., Saari, J., Kalkofen, M., Partanen, J. and Pyrhönen, O (2016). Technical, economic and uncertainty modelling of a wind farm project. Energy Conversion and Management, 107, 22 - 33.

Akella, A., Saini, R. and Sharma, M. (2009). Social, economic and environmental impacts of renewable energy systems', Renewable Energy, 34, 390 - 396.

Allan, G., Eromenko, I., Gilmartin, M., Kockar, I. and McGregor, P. (2015). The economics of distributed energy generation: A literature review. Renewable and Sustainable Energy Reviews, 42, 2015, 543-556.

Ardizzon, G., Cavazzini, G. and Pavesi, G. (2014). A new generation of small hydro and pumped-hydro power plants: advances and future challenges. Renewable and Sustainable Energy Reviews, 31, 746 - 761.

Australian Energy Market Operator (AEMO) [Online], http://www.aemo.com.au/.

Banerjee, R. (2006). Comparison of options for distributed generation in India. Energy Policy, 34, $101-111$.

Bansal, R. (2017) Handbook of Distributed Generation - Electric Power Technologies, Economics and Environmental Impacts, Springer International Publishing AG, Switzerland.

Baxter, R. (2006) Energy storage: a nontechnical guide, Tulsa, OK: PennWell. 
Bizon, N. (2018). Effective mitigation of the load pulses by controlling the battery/SMES hybrid energy storage system. Applied Energy, 229, 459-473.

Bond, T. and Templeton, M. (2011). History and future of domestic biogas plants in the developing world. Energy for Sustainable Development, 15(4), 347 - 354.

Borbely, A.M. and Kreider, J.F. (2001) Distributed Generation, The Power Paradigm for the New Millennium. Boca Raton: CRC Press, USA.

Bradbury, K. (2010) Energy storage technology review. Technical report, Durham, NC: Duke University.

Brearley, J. B. and Raja Prabu, R. (2017). A review on issues and approaches for microgrid protection. Renewable and Sustainable Energy Reviews, 67, 988-997.

Brouwer, A. S., Mvd Broek, Özdemir, Ö., Koutstaal, P. and Faaij, A (2016). Business case uncertainty of power plants in future energy systems with wind power. Energy Policy, 89, 237-56.

Carley, S. (2009). Distributed generation: an empirical analysis of primary motivators. Energy Policy, 37(5), $1648-1659$.

Chambers, A. (2001) Distributed generation: a non-technical guide. Oklahoma: Pennwell, Tulsa.

Chiradeja, P., Ramakumar, R. (2004). An approach to quantify the technical benefits of distributed generation. IEEE Transactions on Energy Conversion, 19, 764 - 73.

Chmutina, K. and Goodier, C., I. (2014). Alternative future energy pathways: assessment of the potential of innovative decentralised energy systems in the UK. Energy Policy, 66, 62 -72 .

CIGRE Study Committee 37 (WG 37-23) (1998) Impact of increasing contribution of dispersed generation on the power system Final Report, CIGRE, Paris.

Colmenar, S., A., Reino, R., C., Borge, D., D. and Collado, F., E. (2016). Distributed generation: a review of factors that can contribute most to achieve a scenario of DG units embedded in the new distribution networks. Renewable and Sustainable Energy Reviews, 59,1130 - 1148 .

Delfanti, M., Falabretti, D. and Merlo, M. (2013). Dispersed generation impact on distribution network losses. Electric Power Systems Research, 97,10 - 18.

Dondi, P., Bayoumi, D., Haederli, C., Julian, D. and Suter, M. (2002). Network integration of distributed power generation', Journal of Power Sources, 106, 1-9.

Electric Power Research Institute. [Online] http://www.epri.com/gg/newgen/disgen/index.html (January 1998)

Engelhardt, S., Erlich, I., Feltes, C., Kretschmann, J. and Shewarega, F. (2011). Reactive power capability of wind turbines based on doubly fed induction generators. IEEE Transactions on Energy Conversion, 26(1), 364 - 372.

Ferreira, J. H. I., Camacho, J. R., Malagoli, J. A. and Guimarães Júnior, S.C. (2016). Assessment of the potential of small hydropower development in Brazil. Renewable and Sustainable Energy Reviews, 56, 380-387.

Florensa, R. S. and Cueva, R. L. (2003). Photovoltaic systems: case studies in Practical handbook of photovoltaics-fundamentals and applications, Elsevier, Amsterdam, pp. 726-747

Gas Research Institute (1998). Distributed Power Generation: A Strategy for a Competitive Energy Industry, Gas Research Institute, Chicago, USA.

Gehlot, R., Pardikar, K., Dasila, N. K. and Mohanty, S. (2016) Solar PV. Integrated World Super Grid (WSG): possibilities, implementation issues and impacts. Journal of Clean Energy Technology, 4(1), $20-5$.

Government of India (GOI) (2018) Annual Report 2018 - 19, Ministry of Non - Renewable Energy, India.

Hadisaid, N., Canard, J. F. and Dumas, F. (1999). Dispersed generation impact on distribution networks. IEEE Computer Applications in Power, 12(12), 22-28.

IEA (2014) Energy storage technology roadmap. International Energy Agency, Paris, France.
Institute of Electrical and Electronics Engineers (IEEE) (2003) IEEE - 1547, Standard for Interconnecting Distributed Resources with Electric Power Systems.

International Energy Agency (IEA) (1997) Energy Technologies for the 21st Century, Paris.

International Energy Agency (IEA) (2002) Distributed generation in liberalized electricity markets. France.

Ishchenko, D., Oudalov, A. and Stoupis, J. (2012). Protection coordination in active distribution grids with IEC 61850 in IEEE PES Transmission and Distribution Conference and Exposition (T\&D), $1-6$.

Jain, S.; Kalambe, S.; Agnihotri, G.; and Mishra, A. (2017). Distributed generation deployment: state - of - the - art of the distribution system planning in sustainable era. Renewable and Sustainable Energy Reviews, 77, $363-385$.

Jenkins, N., Allan, R., Crossley, P., Kirschen, D. and Strbac, G. (2000) Embedded Generation, The Institute of Electrical Engineers, London.

Jenkins, N., Ekanayake, J. B. and Strbac, G. (2010) Distributed Generation, 1st ed., IET, UK.

Khalesi, N., Rezaei, N. and Haghifam, M. R. (2011). DG allocation with application of dynamic programming for loss reduction and reliability improvement. International Journal of Electrical Power and Energy System. 33(2), 88-295.

Khattam, W. El. and Salama, M. (2004). Distributed generation technologies, definitions and benefits. Electric Power Systems Research, 71, $119-128$.

Labouret, A. and Villoz, M. (2010) Solar photovoltaic energy, Institution of Engineering and Technology, United Kingdom.

Latran, M. B., Teke, A. and Yoldas, Y. (2015). Mitigation of power quality problems using distribution static synchronous compensator: a comprehensive review. IET Power Electronics, 8(7), 1312-1328.

Lopes, V. S. and Borges, C. L. T. (2015). Impact of the combined integration of wind generation and small hydropower plants on the system reliability. IEEE Transactions on Sustainable Energy, 6(3), 1169 - 1177.

Mahat, P., Chen, Z. and Bak Jensen, B. (2010). Under frequency Load Shedding for an Islanded Distributed System with Distributed Generation. IEEE Transactions on Power Delivery, 25(2), 911 - 918 .

Mahmud, M. A., Hossain, M. J. and Pota, H. R. (2014). Voltage variation on distribution networks with distributed generation: worst case scenario. IEEE Systems Journal, 8, $1096-1103$.

Mahmud, N. and Zahedi, A. (2016). Review of control strategies for voltage regulation of the smart distribution network with high penetration of renewable distributed generation. Renewable Sustainable Energy Reviews, 64, 582 - 95.

Manfren, M., Caputo, P. and Costa, G. (2011). Paradigm shift in urban energy systems through distributed generation: methods and models. Applied Energy, 88(4),1032 - 1048.

Mehigan, L., Deane, J.P., Gallachóir, B.P.Ó. and Bertsch, V. (2018). A review of the role of distributed generation (DG) in future electricity systems. Energy,163, $822-836$.

National Renewable Energy Laboratory (2003). Gas fired distributed energy resource technology characterizations. [Online] http://www.nrel.gov/docs/fy04osti/34783.pdf. (Accessed on 21 Apr 2016).

Paliwal, P., Patidar, N. P. and Nema, R. K. (2014). Planning of grid integrated generators: a review of technology, objectives and planning. Renewable and Sustainable Energy Reviews, $40,557-570$.

Pepermans, G., Driesen, J., Haeseldonckx, D., Belmans, R. and D'haeseleer, W. (2005). Distributed generation: definition, benefits and issues', Energy Policy, 33(6), 787-798.

Perez-Arriaga, I. J. (2016). The transmission of the future: the impact of distributed energy resources on the network', IEEE Power and Energy Magazine, 14(4), 41-53.

Roy, N. and Pota, H. R. (2015). Current status and issues of concern for the integration of distributed generation into electricity networks. IEEE Systems Journal, 9, 933 - 44. 
San Martín, J. I., Zamora, I., San Martín, J. J., Aperribay, V. and Eguia, P. (2010). Hybrid fuel cells technologies for electrical microgrids. Electric Power Systems Research, 80, 993-1005.

Soroudi, A., Ehsan, M., Caire, R. and Hadjsaid, N. (2011) Possibilistic evaluation of distributed generations impacts on distribution networks. IEEE Transactions on Power Systems, 26(4), 2293 - 2301.

Strachana, N. and Farrell, A. (2006). Emissions from distributed vs. centralized generation: the importance of system performance', Energy Policy, 34, 2677-2689.
Vahl, F., P., Rüther, R. and Casarotto, F., N. (2013). The influence of distributed generation penetration levels on energy markets', Energy Policy, 62, 226 - 235.

VanVuuren, S. J., VanDijk, M., Loots, I., Barta, B. and Scharfetter, B. G. (2014). Conduit hydropower development guide. Water Research Commmission, Pretoria.

Willis, H. L. and Scott, W. G. (2000) Distributed power generation, Marcel Dekker, New York.

Zahedi, A. (2011). A review of drivers, benefits, and challenges in integrating renewable energy sources into electricity grid. Renewable and Sustainable Energy Reviews, 15, 4775 - 4779.

(C) 2020. This article is an open access article distributed under the terms and conditions of the Creative Commons Attribution (CC BY) license (http://creativecommons.org/licenses/by/4.0/) 